\title{
Benthic invertebrate communities on three seamounts off southern and central California, USA
}

\author{
Lonny Lundsten ${ }^{1, *}$, James P. Barry ${ }^{1}$, Gregor M. Cailliet ${ }^{2}$, David A. Clague ${ }^{1}$, \\ Andrew P. DeVogelaere ${ }^{3}$, Jonathan B. Geller ${ }^{2}$ \\ ${ }^{1}$ Monterey Bay Aquarium Research Institute, 7700 Sandholdt Road, Moss Landing, California 95039-9644, USA \\ ${ }^{2}$ Moss Landing Marine Laboratories, 8272 Moss Landing Road, Moss Landing, California 95039, USA \\ ${ }^{3}$ Monterey Bay National Marine Sanctuary, 299 Foam Street, Monterey, California 93940, USA
}

\begin{abstract}
Seamounts are unique and biologically productive deep-sea habitats that have often been described as having high levels of endemism, highly productive fisheries, and benthic communities vulnerable to trawl fishing. We describe the abundance and distribution of benthic megafaunal invertebrates found on 3 seamounts off central and southern California. Video observations were taken during 27 dives of a remotely operated vehicle (ROV) and were annotated in detail using the Monterey Bay Aquarium Research Institute's (MBARI) video annotation reference system (VARS, http://vars.sourceforge.net/). Video analysis yielded 134477 observations of 202 identified invertebrate taxa. Video transects were analyzed to quantify organism density. Thirteen new species were observed and collected. Invertebrate communities at Davidson and Pioneer Seamounts were dominated by passive suspension-feeding cnidarians (mostly corals), but at Rodriguez Seamount, a guyot, the invertebrate community was dominated by holothurian echinoderms. We found no evidence of endemism among the megafauna at these 3 seamounts, which are all in close proximity to each other and the continental margin.
\end{abstract}

KEY WORDS: Seamount biology $\cdot$ Deep-sea corals $\cdot$ Seamount invertebrate communities $\cdot$ Endemism Resale or republication not permitted without written consent of the publisher

\section{INTRODUCTION}

Seamounts are biologically productive habitats, often with biological assemblages dominated by longlived corals and dense aggregations of fishes, where species-rich benthic communities thrive (Rogers 1994, Koslow 1997, Richer de Forges et al. 2000, Koslow et al. 2001, Andrews et al. 2002, Grigg 2002, Risk et al. 2002, Rowden et al. 2002, Stocks 2004, Mortensen \& BuhlMortensen 2005). The distribution, diversity, and abundance of benthic organisms on seamounts has been attributed to various factors, including substrate type, local hydrographic conditions, reproductive modes, proximity to sources of larvae, geographic location, seamount topography, entrapment of migrating zooplankton, and elevated current velocities (Genin et al. 1988, Boehlert \& Genin 1987, Grigg et al. 1987, Wilson \& Kaufmann 1987, Parker \& Tunnicliffe 1994, Rogers 1994, Mullineau \& Mills 1996, Richer de Forges et al. 2000, White \& Mohn 2004). Seamounts have been the focus of commercial fisheries, including many that have collapsed due to over-harvesting of slowly reproducing stocks (Koslow 1997, Koslow et al. 2001, McClatchie \& Coombs 2005). Incidental effects of commercial trawling have decimated benthic invertebrate communities on many seamounts (Koslow et al. 2001, Fosså et al. 2002, Fry et al. 2006).

Despite the potential for anthropogenic disturbance and our lack of understanding of processes that regulate the structure and population dynamics of seamount communities, few studies have addressed faunal turnover between these communities or the abiotic factors affecting their composition. Kaufmann et al. (1989) attributed differences in community structure to hydrodynamic conditions as well as substrate and nutrient availability when describing megafaunal communities from 2 North Pacific seamounts. Probert et al. (1997) detected differences in the faunal composition 
of bycatch collected on the pinnacles and flats on the Chatham Rise. At least 2 studies have attributed higher densities of organisms, particularly corals, to areas identified as localized 'peaks' or areas of elevated topography (Genin et al. 1986, DeVogelaere et al. 2005). However, none of these studies provides a comprehensive view of factors influencing the function of seamount benthic communities in general.

We examined 3 seamounts along the California continental margin. Davidson, Pioneer, and Rodriguez Seamounts (Fig. 1) are each 9 to 16 million yr (myr) old, have similar volcanic origins, and are located atop older oceanic crust that formed 19 to 20 myr ago (Davis et al. 2002). Though formed under similar conditions, the topography, size, and summit depth of these seamounts vary (Table 1). Davidson and Pioneer Seamounts, located at the base of the continental slope 80 to $90 \mathrm{~km}$ from shore, have peaked summits with cones arranged along parallel ridges separated by sedimentfilled troughs. Rodriguez Seamount, $250 \mathrm{~km}$ south of Davidson Seamount, is only $\sim 60 \mathrm{~km}$ from shore with its base midway up the continental slope. Approximately 10 myr old, Rodriguez Seamount was exposed subaerially and is now a flat-topped seamount or guyot. Like Davidson and Pioneer, Rodriguez has rugged flanks, but its summit consists of lithified sandy beach deposits with a thin sediment veneer.

In the present study, we describe the benthic invertebrate communities observed on the 3 California seamounts described above. In addition, we compare the major invertebrate taxa among these seamounts in relation to abiotic properties, to infer the potential role of abiotic factors in regulating the structure of the seamount communities.

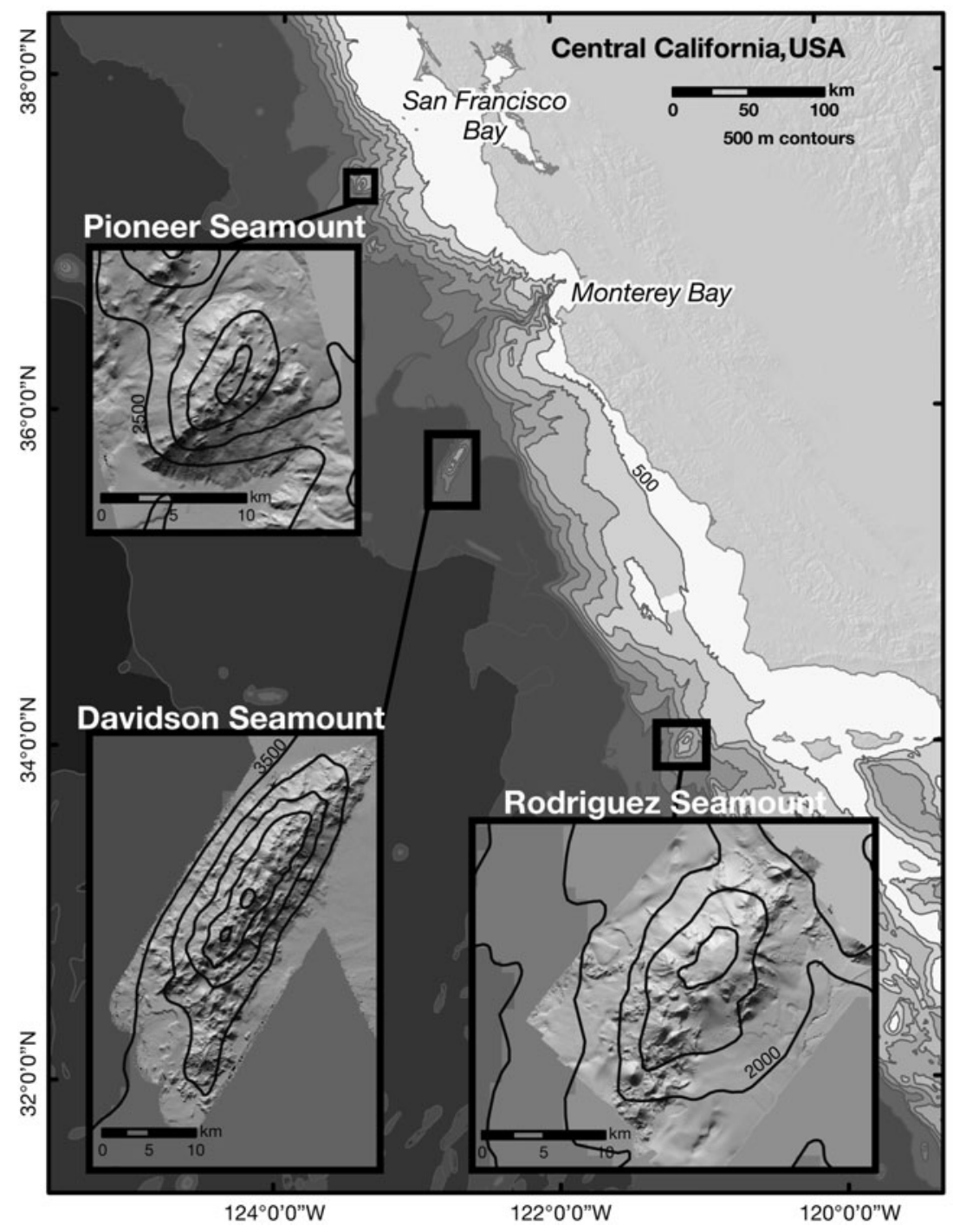

Fig. 1. Davidson, Pioneer, and Rodriguez Seamounts off central California

\section{MATERIALS AND METHODS}

Seamount communities were sampled using Monterey Bay Aquarium Research Institute's (MBARI) remotely operated vehicle (ROV) 'Tiburon'. Sampling included video observations recorded using high-resolution video equipment and collections of specimens for taxonomic determinations. Seamount community composition was determined from the analysis of $191 \mathrm{~h}$ of video taken during 27 dives on the 3 seamounts. The video was annotated in detail using MBARI's video annotation and reference system (VARS) (Schlining \& Jacobsen Stout 2006).

Video data were collected from various depths at each seamount. Davidson Seamount was sampled from its summit at $1246 \mathrm{~m}$ to a depth of $3289 \mathrm{~m}$ ( $90 \%$ of seamount depth range sampled) (Table 1). Pioneer Seamount was sampled from its summit at $811 \mathrm{~m}$ to a depth of $1815 \mathrm{~m}$ (66\% of seamount depth range sampled). Rodriguez Seamount was sampled from its summit at $619 \mathrm{~m}$ to a depth of $2120 \mathrm{~m}$ (91 \% of seamount depth range sampled).

All benthic invertebrates were identified to the lowest possible taxon using in situ video frame grabs and digital still images of voucher specimens that were identified by taxonomists. When possible, voucher specimens were collected using the ROV manipulator, the 
Table 1. Seamount dimensions, distance from shore, and depths sampled

\begin{tabular}{|lccccccc|}
\hline Seamount & $\begin{array}{c}\text { Length } \\
(\mathrm{km})\end{array}$ & $\begin{array}{c}\text { Width } \\
(\mathrm{km})\end{array}$ & $\begin{array}{c}\text { Base depth } \\
(\mathrm{m})\end{array}$ & $\begin{array}{c}\text { Summit depth } \\
(\mathrm{m})\end{array}$ & $\begin{array}{c}\text { Depths sampled } \\
(\mathrm{m})\end{array}$ & $\begin{array}{c}\text { Proportion of total } \\
\text { depth sampled }(\%)\end{array}$ & $\begin{array}{c}\text { Distance from } \\
\text { shore }(\mathrm{km})\end{array}$ \\
\hline Davidson & $\sim 42$ & $\sim 13.5$ & 3656 & 1246 & $1256-3289$ & 90 & $\sim 90$ \\
Pioneer & $\sim 12.8$ & $\sim 12.8$ & 2750 & 811 & $811-1815$ & 66 & $\sim 80$ \\
Rodriguez & $\sim 12.8$ & $\sim 12.8$ & 2325 & 619 & $619-2120$ & 91 & $\sim 60$ \\
\hline
\end{tabular}

ROV suction sampler or, in some cases, they were removed from rock samples collected for other research objectives. Voucher specimens were not collected for organisms that could be identified easily from video and which were known to occur on the California shelf and in Monterey Canyon. When voucher specimens were not collected and the animal was not known by the video analyst, video frame grabs, digital still images, and/or video segments were reviewed by taxonomists with expertise in the taxonomic group of the organism in question, and the resulting identification was then used as a reference during detailed video analysis. Although every effort was made to identify organisms to the lowest possible taxon, assignment to species was not always possible. For organisms that were morphologically distinct, but not sampled, and therefore not identified to species level, a 'tag' name was applied within the VARS database (e.g. Echinoidea sp. 1).

Plots of cumulative species richness versus total distance traversed with the ROV were used to evaluate adequacy of sampling for the 3 dominant invertebrate groups (corals, echinoderms, and sponges). Curves were calculated using EstimateS version 8.0 (Colwell 2005) and were plotted for each seamount using $1 \mathrm{~km}$ bins of the total distance traversed and species presence/absence data within those bins.

Quantitative video transects were collected at Davidson Seamount in 2006 and Pioneer Seamount in 2007 and were used to estimate the density of invertebrate megafauna. A total of 40 transects was analyzed (Davidson, $\mathrm{n}=33$; Pioneer, $\mathrm{n}=7$ ). Two parallel red laser beams (640 nm), positioned $29 \mathrm{~cm}$ apart, were used to estimate transect width. Transect length was calculated in ArcView ${ }^{\circledR} 3.2$ using the Animal Movement Analysis Extension version 2 to calculate successive distance between the start and end points of each transect (Hooge \& Eichenlaub 1997). A 2-tailed $t$-test was used to compare differences between the mean density found at Davidson and Pioneer Seamounts.

Categories of motility and feeding mode were assigned to all observed taxa and analyzed to determine the functional roles of dominant members of the seamount communities. Because the feeding modes of many organisms identified in the present study are uncertain, we assigned modes for these taxa based on information for morphologically similar organisms from shallow waters. The functional groups assigned included passive suspension-feeding (corals, crinoids, brisingids), filter-feeding (sponges and tunicates), deposit-feeding (echinoids and holothurians), and carnivory (primarily asteroids) (Brusca \& Brusca 1990, Gage \& Tyler 1992). Organism motility was classified as sessile (e.g. corals, sponges, stalked crinoids, tunicates), functionally sessile (e.g. brisingids and crinoids), and mobile (e.g. asteroids, echinoids, and holothurians).

To evaluate faunal similarity among seamount communities, Bray-Curtis coefficients were calculated based on standardized and 4th-root transformed abundance data from each seamount using Primer v6 (Clarke \& Gorley 2001).

\section{RESULTS}

In total, 134477 observations of 202 invertebrate taxa were derived from video observations of the 3 seamounts examined. At Davidson, Pioneer, and Rodriguez Seamounts, we identified 59933, 36430 , and 38087 individuals belonging to 148, 110, and 133 taxa, respectively. In all, 225 specimens were collected and sent to taxonomists for identification; 13 of these are new to science and have recently been or are currently being described (e.g. Cairns 2007, Reiswig \& Lee 2007, G. C. Williams \& L. Lundsten unpubl.).

Smoothed cumulative taxa curves begin to approach an asymptote after an ROV transit length of $\sim 10 \mathrm{~km}$ (Fig. 2). Based on this, we assumed that corals, sponges, and echinoderms were characterized adequately by video analysis.

Quantitative video transects at Davidson and Pioneer Seamounts differed in mean organism density. Thirtythree transects were collected between 1298 and $3276 \mathrm{~m}$ depth at Davidson Seamount. These transects varied in length (45 to $445 \mathrm{~m}$ ) and width (0.97 to $8.17 \mathrm{~m})$. Organism density averaged $0.87 \pm 0.10$ ind. $\mathrm{m}^{-2}$ (range $=0.1$ to 2.2 ind. $\mathrm{m}^{-2}$ ). Seven transects were collected between 844 and $1240 \mathrm{~m}$ at Pioneer Seamount. These transects varied in length (66.8 to $261.6 \mathrm{~m}$ ) and width (1.57 to $2.62 \mathrm{~m}$ ). Organism density averaged $2.19 \pm 0.27$ ind. $\mathrm{m}^{-2}$ (range $=1.1$ to 3.2 ind. $\mathrm{m}^{-2}$ ). Mean organism density was significantly different between Davidson and Pioneer Seamounts, $t(38)=-5.13, \mathrm{p}<0.001$. 

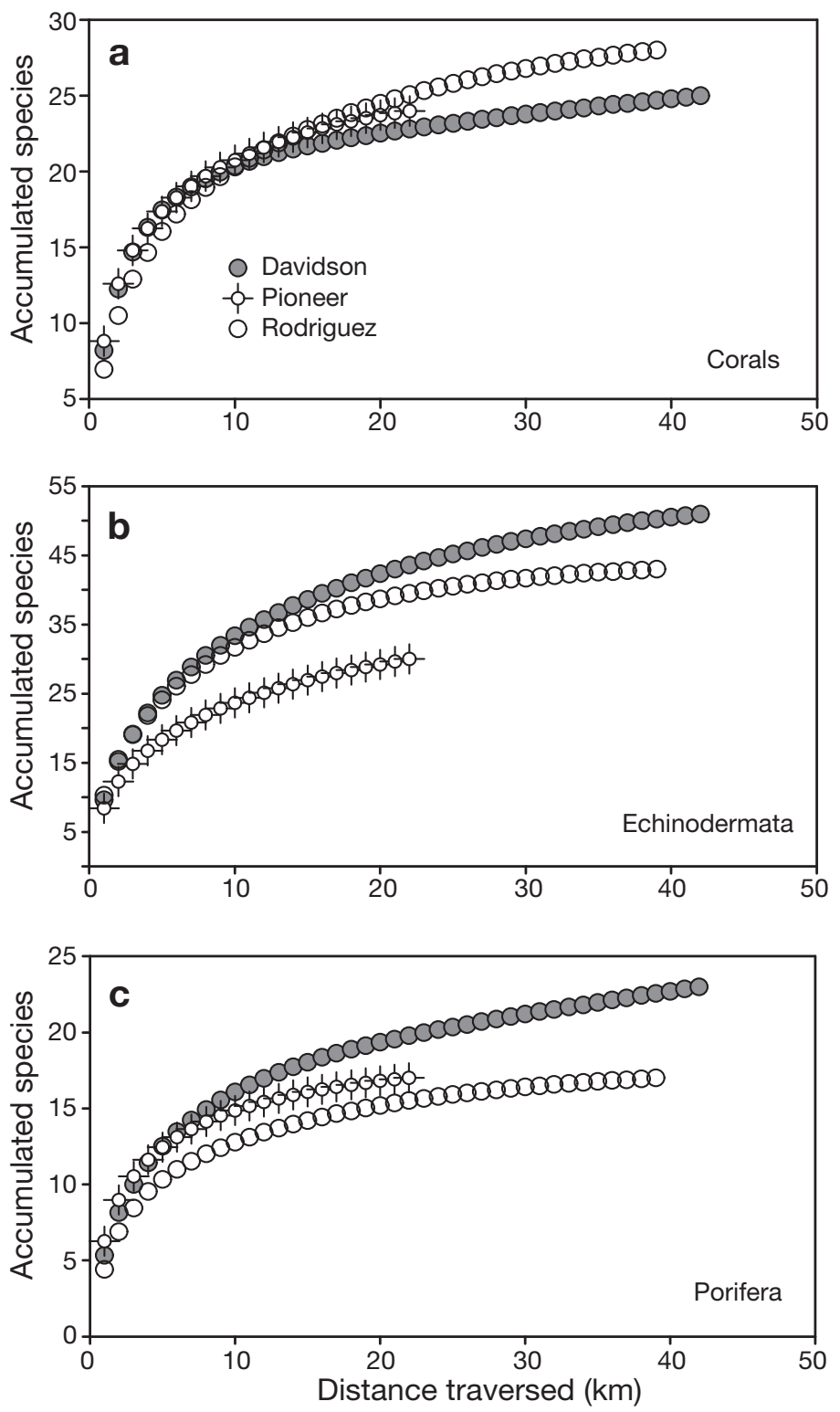

Fig. 2. Smoothed species accumulation curves for the major assemblages of megafaunal invertebrates: (a) corals, (b) echinoderms, (c) sponges. In all panels, the $y$-axis is the accumulated species and the $x$-axis is the distance traversed by the remotely operated vehicle (ROV) (in km)

Qualitative video observations revealed that Cnidaria, Porifera, and Echinodermata were the dominant phyla at all 3 seamounts, although their relative dominance varied among locations. Cnidarians were the most frequently observed phylum at Davidson $(34.2 \%)$ and Pioneer Seamounts (39.8\%). At Rodriguez Seamount, despite making up $35.6 \%$ of the observed population, cnidarians were observed less frequently than echinoderms (Fig. 3). Echinoderms were common on all 3 seamounts and accounted for 32.4, 34.4, and $45.5 \%$ of the observations at Davidson, Pioneer, and

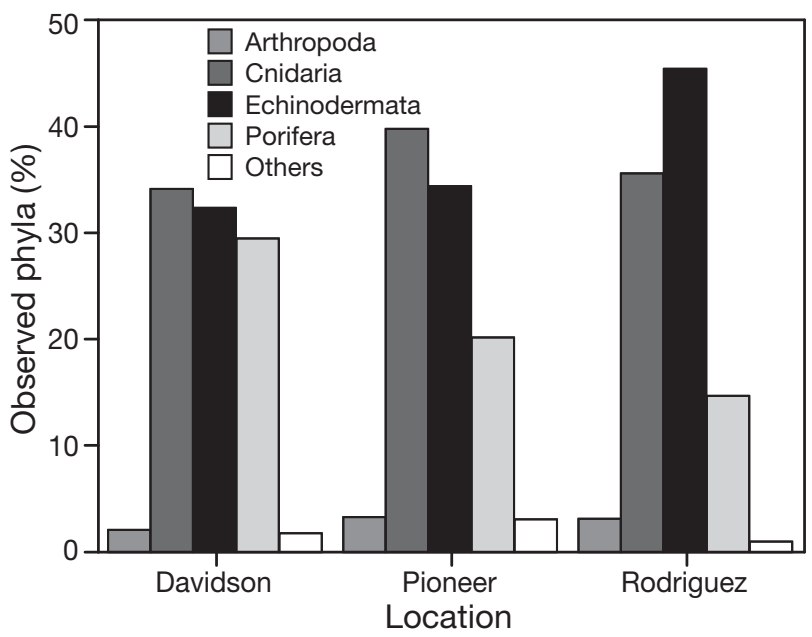

Fig. 3. Percent observation of invertebrate phyla at Davidson, Pioneer, and Rodriguez Seamounts. Annelida, Ectoprocta, Echiura, Hemichordata, Mollusca, Nemertea, Protista, and Urochordata have been combined as 'Others'

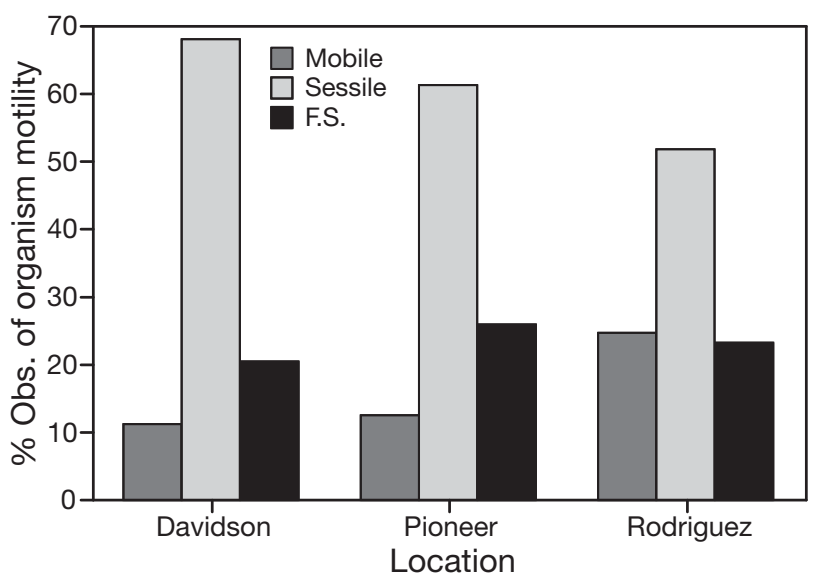

Fig. 4. Percent of total observations among motility modes for seamount organisms at Davidson, Pioneer, and Rodriguez Seamounts. F.S.: functionally sessile

Rodriguez Seamounts, respectively. Sponges were observed more frequently at Davidson Seamount $(29.5 \%)$ than at Pioneer $(20.2 \%)$ or Rodriguez $(14.7 \%)$ Seamounts.

Sessile and functionally sessile animals accounted for most of the observations. When combined, functionally sessile and sessile organisms represented 88.8, 87.4, and $75.2 \%$ of the observations, respectively, at Davidson, Pioneer, and Rodriguez Seamounts (Fig. 4).

Analysis of categorized feeding modes indicated that suspension-feeding was most common for invertebrate assemblages at all 3 seamounts. At Davidson Seamount $58.5 \%$ of the organisms were suspension-feeders, $29.9 \%$ were filter-feeders, $8.5 \%$ were detritivores, and $3.1 \%$ were carnivores (Fig. 5). At Pioneer Seamount, most of the observed taxa were categorized as suspension- $(67.8 \%)$ and filter- $(19.6 \%)$ feeders. Detritivores 


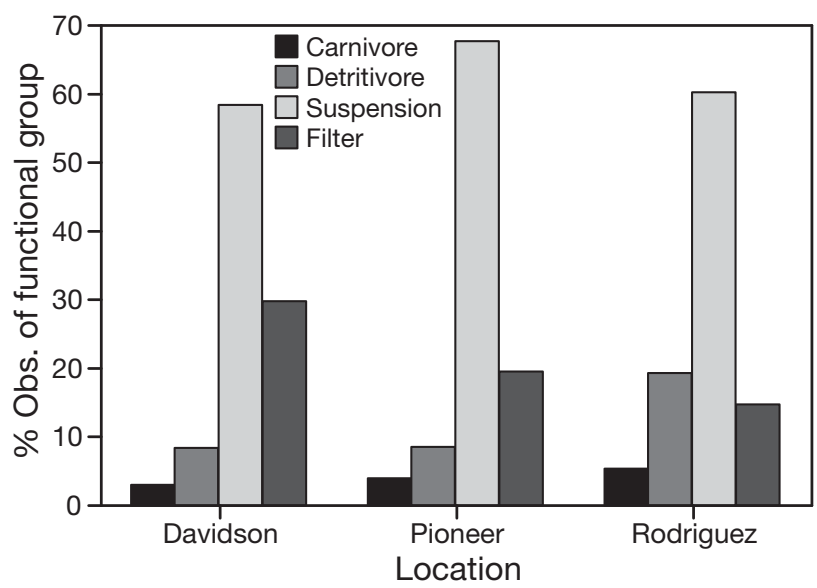

Fig. 5. Percent of total observations among functional groups for seamount organisms at Davidson, Pioneer, and Rodriguez Seamounts

$(8.6 \%)$ and carnivores $(4.0 \%)$ were observed less frequently. At Rodriguez Seamount, most organisms were suspension-feeders $(60.3 \%)$, followed by detritivores $(19.4 \%)$, filter-feeders $(14.8 \%)$, and carnivores $(5.5 \%)$.

The group of cnidarians referred to herein as 'corals' (as defined in Deep-Sea Coral Collection Protocols, Etnoyer et al. 2006) dominated the cnidarian observations, and we focused our cnidarian analysis on this taxonomically mixed group, which includes alcyona- ceans, antipatharians, gorgonians, pennatulaceans, scleractinians, and zoanthid anemones. Alcyonaceans were abundant at Pioneer (38.6\%) and Rodriguez $(19.6 \%)$ Seamounts and had a mean depth of observation between 800 and $950 \mathrm{~m}$ at both locations (Fig. 6). Alcyonaceans were less frequently observed at Davidson Seamount $(4.7 \%)$, where the mean depth of observation was $\sim 2000 \mathrm{~m}$. Antipatharians were observed frequently at Davidson Seamount $(21.8 \%)$ and had a mean depth of observation of $\sim 2125 \mathrm{~m}$; however, they were infrequently observed at Pioneer (0.2\%) and Rodriguez (0.07\%) Seamounts. The Gorgonacea were the most frequently observed coral group (Davidson = $73 \%$; Pioneer $=61 \%$; Rodriguez $=74.6 \%$ ) and encompassed the widest depth range at all 3 seamounts, although the mean depth of observation varied. Pennatulaceans were rare at Davidson and Pioneer Seamounts, but accounted for $5.5 \%$ of coral observations at Rodriguez Seamount, where the mean depth of observation was $\sim 750 \mathrm{~m}$. Scleractinian corals (Davidson $=0.4 \%$; Pioneer $=0.15 \%$; Rodriguez $=0.12 \%$ ) and zoanthid anemones (Davidson $=0.09 \%$; Pioneer $=0.0 \%$; Rodriguez $=0.07 \%$ ) were rare at all 3 seamounts. At Davidson Seamount, 25 coral species were identified; abundant species there include Trissopathes pseudotristicha, Corralium sp., Keratoisis sp., Paragorgia arborea, Parastenella sp., Anthomastus ritteri, and

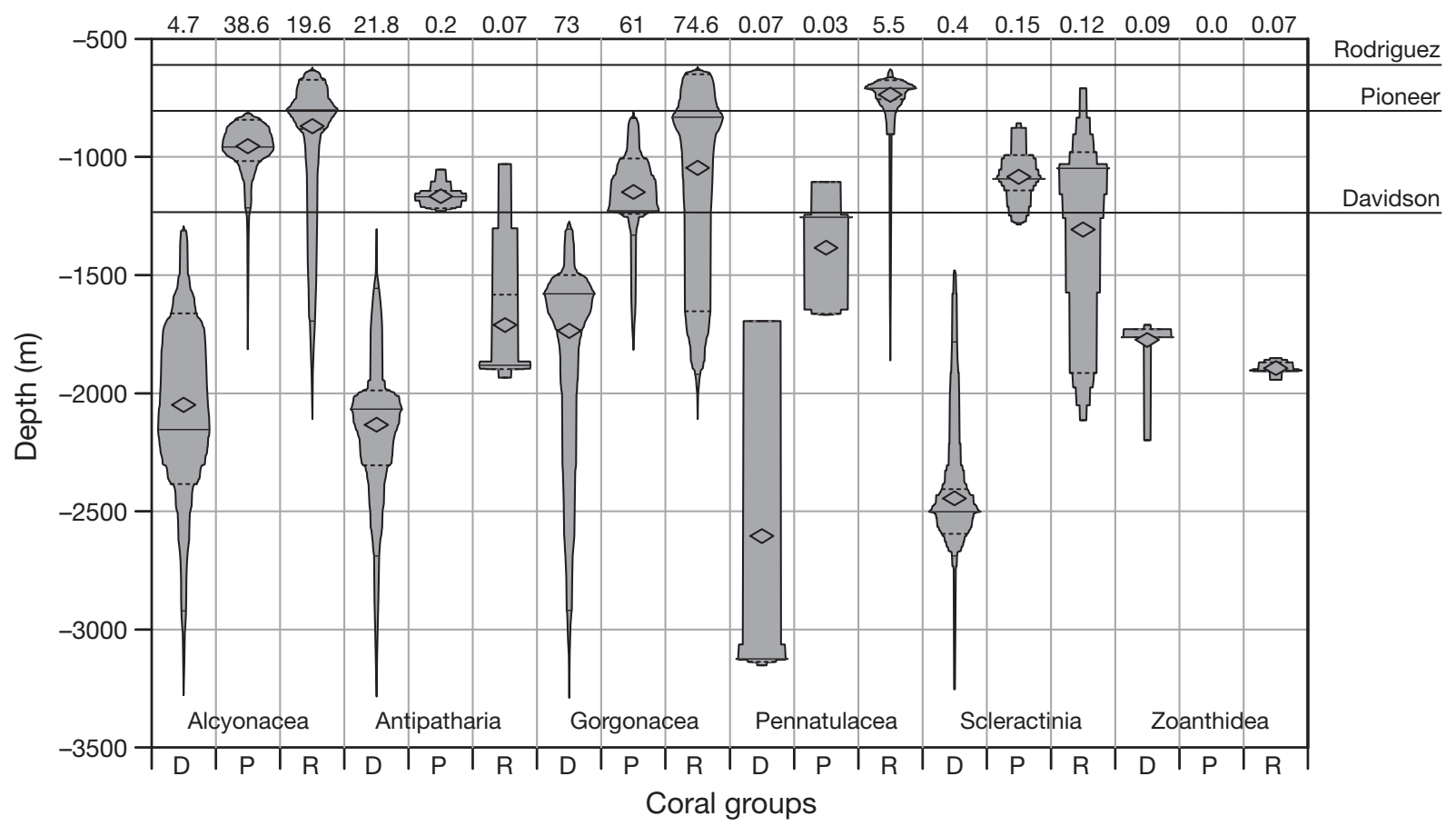

Fig. 6. Depth distributions of abundant coral groups at Davidson (D), Pioneer (P), and Rodriguez (R) Seamounts. Mean depth $(\diamond)$. Width of each distribution polygon at any given depth is proportional to the percentage of observations at that depth. (---) 25th and 75th percentile for all observations; (-) summit depth for each seamount, labeled (right) with the seamount name. Values at the top of each column indicate the percentage of all corals accounted for by that coral class (listed below) on each seamount (indicated on the $x$-axis by D, P, or R). Total number of corals observed were $\mathrm{n}=18191$ (D), 13817 (P), and 12316 (R) 
Acanthogorgia sp. Several species of the Primnoidae, which were also abundant at Davidson, were counted as one taxon since they were indistinguishable in the video footage. At Pioneer Seamount, 23 species of coral were identified. The alcyonacean Anthomastus ritteri was the most abundant coral and the secondmost abundant organism observed there. The gorgonian corals Lepidisis sp., Isidella sp., Keratoisis sp., Acanthogorgia sp., Swiftia kofoidi, Paragorgia sp., Swiftia simplex, and Paragorgia arborea were also observed frequently at Pioneer Seamount. At Rodriguez Seamount, 26 species of coral were identified, and abundant species include Anthomastus ritteri, Isidella sp., Narella sp., Parastenella sp., Acanthogorgia sp., Paragorgia sp., Keratoisis sp., Anthoptilum grandiflorum, and Swiftia simplex.

Crinoid echinoderms dominated the megafaunal observations at Davidson and Pioneer Seamounts, in contrast with Rodriguez Seamount, where holothurians played the largest role (Fig. 7). The Asteroidea were observed at a relatively similar frequency at Davidson $(10.3 \%)$, Pioneer $(9 \%)$, and Rodriguez (13.7\%) Seamounts, but had a mean depth of observation far deeper at Davidson $(2200 \mathrm{~m})$ than at Pioneer $(1200 \mathrm{~m})$ or Rodriguez $(1050 \mathrm{~m})$. Crinoids were the most frequently observed echinoderm class at Davidson $(44.6 \%)$ and Pioneer $(61.7 \%)$ Seamounts, but they were observed less frequently than holothurians at Rodriguez Seamount $(22.2 \%)$. Crinoids had a mean depth of observation of $2600 \mathrm{~m}$ at Davidson Seamount and were observed at shallower depths at Pioneer $(\sim 1150 \mathrm{~m})$ and Rodriguez $(1600 \mathrm{~m})$ Seamounts. Echinoidea were rare at both Davidson $(0.4 \%)$ and Pioneer $(0.02 \%)$ Seamounts, but were frequently observed at Rodriguez Seamount (14.2\%), where the mean depth of observation was $\sim 1150 \mathrm{~m}$. The Holothuroidea were the most frequently observed class of echinoderm encountered at Rodriguez Seamount $(37.9 \%, 1000 \mathrm{~m}$ mean depth), but they were also observed frequently at both Davidson $(16.1 \%, 2500 \mathrm{~m}$ mean depth) and Pioneer $(23.4 \%, ~ 1200$ m mean depth) Seamounts. Ophiuroidea were observed frequently at Davison Seamount $(28.7 \%, 1650 \mathrm{~m}$ mean depth), where dense aggregations of the suspension-feeding Gorgonocephalus sp. were most common and were often seen clinging to the branches of the gorgonian coral Paragorgia arborea. At Pioneer (5.9\%) and Rodriguez (12\%) Seamounts, ophiuroids had a similar mean depth of observation at 1200 m. Florometra serratissimia and Gorgonocephalus sp. were the most commonly observed echinoderm taxa at Davidson Seamount, followed by the holothurian Laetmogone sp. and a stalked crinoid Hyocrinus sp. At Pioneer Seamount, the most frequently observed species was F. serratisima, followed by Psolus squamatus. Unidentified ophiuroids and asteroids were also observed frequently. Species frequently observed at Rodriguez Seamount include P. squamatus, F. serratissima, Araeosoma leptaleum, Pannychia

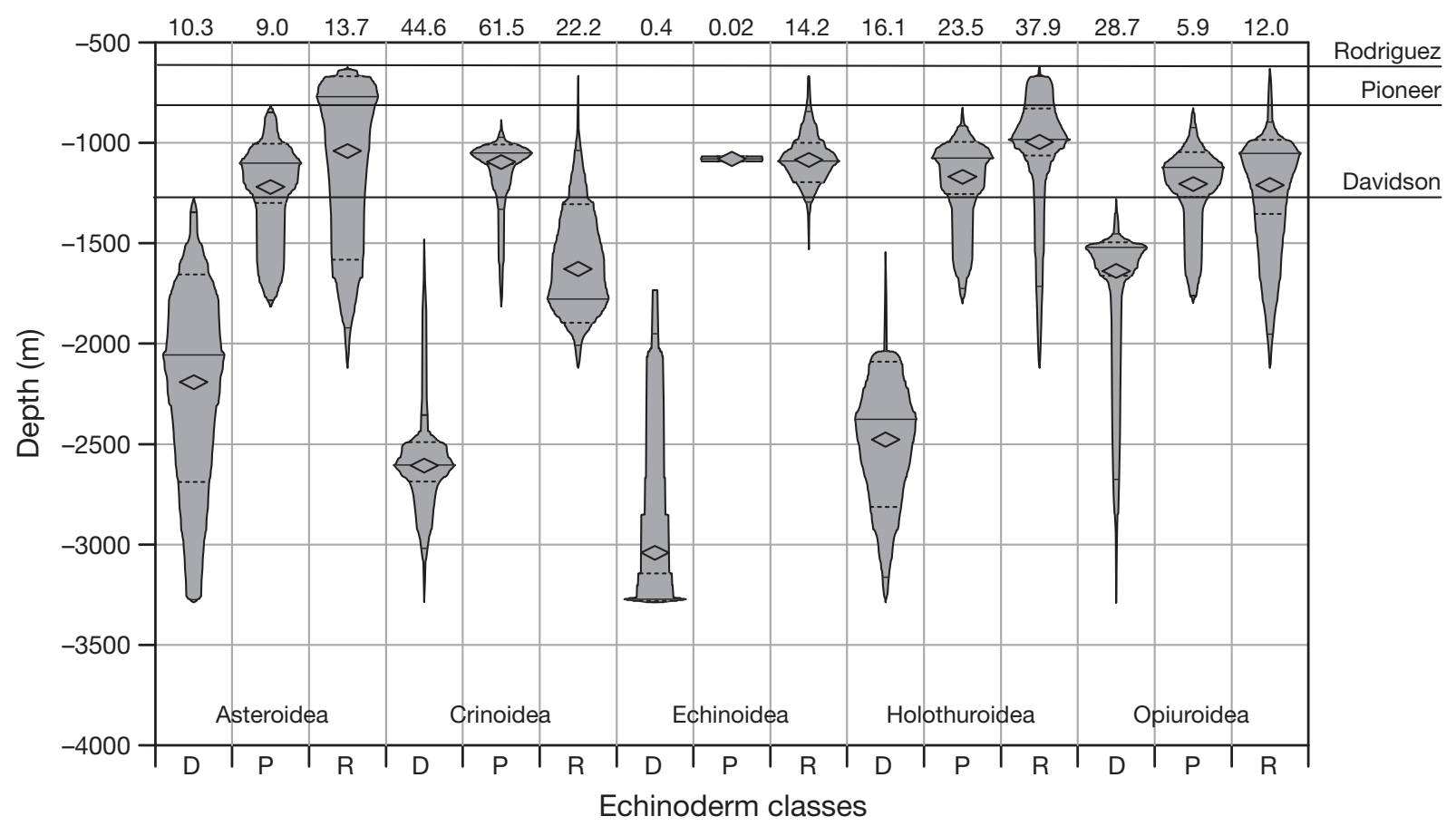

Fig. 7. Depth distribution of echinoderm classes at Davidson (D), Pioneer (P), and Rodriguez (R) Seamounts. Notations as in Fig. 6. Total number of echinoderms observed were $\mathrm{n}=19402(\mathrm{D}), 12543(\mathrm{P})$, and $17320(\mathrm{R})$ 
moseleyi, and 2 species of brisingids that were identified from collected specimens but were indistinguishable in video.

Observations of poriferans at each seamount were often composed of different percentages of the same taxa, such as Chonelasma sp., Farrea sp., Heterochone sp., and Staurocalyptus sp. (Fig. 8). At all 3 seamounts, a large proportion of sponges $(31.9,25.4$, and $34.6 \%$ of observations at Davidson, Pioneer, and Rodriguez, respectively) could not be identified to a lower taxonomic level. At Davidson Seamount, Chonelasma sp. $(6.4 \%, 1600 \mathrm{~m}$ mean depth) was observed at greater depths than at Pioneer $(9.7 \%, 900 \mathrm{~m}$ mean depth) and Rodriguez $(6.5 \%, \sim 900 \mathrm{~m}$ mean depth) Seamounts. Farrea sp. was abundant just below the summits of Davidson $(22.5 \%, 1400 \mathrm{~m}$ mean depth) and Pioneer (11.4\%, 950 m mean depth) Seamounts, but was observed far below the summit at Rodriguez Seamount (47.1\%, 1125 m mean depth). Heterochone sp. had a mean depth of observation of $1400 \mathrm{~m}$ at Davidson Seamount $(5.9 \%)$ and a shallower mean depth of occurrence of $\sim 900$ to $950 \mathrm{~m}$ at both Pioneer $(17.7 \%)$ and Rodriguez (3.2\%) Seamounts. Sclerothamnopsis sp. was abundant at Davidson Seamount (14.8\%, $1650 \mathrm{~m}$ mean depth), but was nearly absent from Pioneer $(1.7 \%, 1025 \mathrm{~m}$ mean depth) and Rodriguez $(0.6 \%$, $1150 \mathrm{~m}$ mean depth) Seamounts. Staurocalyptus sp. was abundant near the summits of both Davidson (13.2\%, $1300 \mathrm{~m}$ mean depth) and Pioneer (13.1\%,
$1150 \mathrm{~m}$ mean depth) Seamounts and, though less abundant, it was found at comparable depths at Rodriguez Seamount (4.1\%, 1200 m mean depth). Thenea muricata was absent from Davidson Seamount, uncommon at Rodriguez Seamount (3.2\%, 900 m mean depth), and abundant at Pioneer Seamount (16.1\%, 1200 m mean depth).

Bray-Curtis similarity indices (B-C) indicated that assemblages of megafaunal invertebrates on Pioneer and Rodriguez Seamounts were more similar to each other (B-C Pioneer-Rodriguez $=63.27 \%$ ) than either of the 2 was to Davidson Seamount (B-C Davidson-Pioneer $=55.85 \%$, B-C Davidson-Rodriguez $=55.04 \%$ ). Of 202 taxa identified in the present study, 117 (57.9\%) were seen at 2 or more of the seamounts described. Of these, $35.6 \%$ were observed at all 3 seamounts. Finally, $22.3 \%$ were seen at Davidson Seamount only, $15.4 \%$ were seen at Rodriguez Seamount only, and $4.5 \%$ were seen at Pioneer Seamount only.

\section{DISCUSSION}

The higher mean density of organisms found on Pioneer Seamount, which has a shallower summit than Davidson Seamount, is likely due to nutrient availability, which decreases with depth globally in concert with an exponential decline in organism abundance and biomass (Rex et al. 2006). However, the shallower

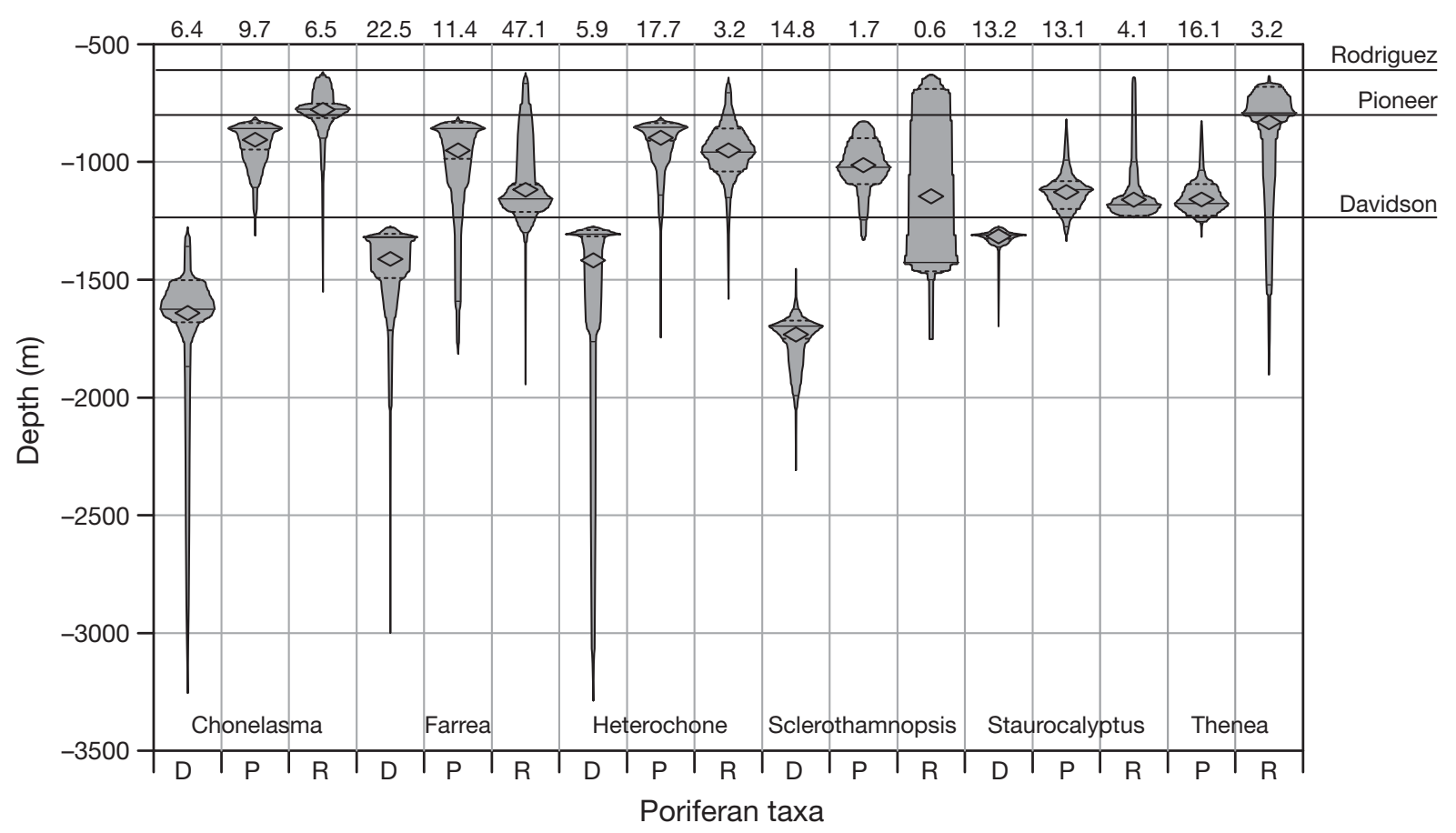

Fig. 8. Depth distribution of abundant poriferan taxa at Davidson (D), Pioneer (P), and Rodriguez (R) Seamounts. Notation as in Fig. 6. Total number of poriferan taxa observed were $n=17692$ (D), 7365 (P), and $5574(\mathrm{R})$ 
depths of transects run on Pioneer versus those on Davidson Seamount limits our ability to infer potential causes of the observed differences in organism density, including depth, habitat differences, reproductive strategies, and rates of larval recruitment or survival (e.g. Gage \& Tyler 1992, Parker \& Tunnicliffe 1994, Mullineau \& Mills 1996).

The dominant feeding mode and range of motility of the observed megafauna appears to be coupled tightly to habitat differences. Megafauna feeding and motility were quite similar on the rugged slopes and peaks of Davidson and Pioneer Seamounts, where sessile suspension-feeders dominated. In contrast, the sedimentladen top of Rodriguez Seamount, a true guyot, was inhabited principally by mobile, deposit-feeding holothurians and echinoids.

The high abundance of octocorals at these eastern Pacific seamounts contrasts sharply with the scleractinian dominance of seamounts in other regions (Wilson \& Kaufmann 1987, Clark et al. 2006) and may be related to several factors. One primary factor could be the shallow (50 to $600 \mathrm{~m}$ ) aragonite saturation depth in the northeast Pacific, which limits the ability of scleractinians to build their hard skeletons (Clark et al. 2006, Guinotte et al. 2006). This is further illustrated by the low percentage of scleractinian observations in the present study, which accounted for only $0.25 \%$ of the total coral observations when data from all 3 seamounts were combined. Gorgonian corals were the most frequently observed coral group at all 3 seamounts; however, frequent observations of antipatharians occurred on deeper slopes at Davidson Seamount. A similar trend of increased observations of antipathrians in deeper water has been noted by Clark et al. (2006). Additionally, the high abundance of pennatulaceans on the sedimented summit of Rodriguez Seamount also indicates a link between faunal patterns and habitat features.

While rare invertebrate species were observed and new species (Cairns 2007, Reiswig \& Lee 2007, G. C. Williams \& L. Lundsten unpubl., C. Mah pers. comm.) discovered in the present study, none appear to be endemic to individual seamounts. For example, while 2 new corals in the genus Chrysogorgia ( $C$. monitcola and C. pinnata) had distinct patterns of distribution (Cairns 2007), they were seen at multiple seamount locations, including the seamounts examined here and several that were visited on other MBARI seamount expeditions, such as the Vance Seamounts to the north and San Juan Seamount to the south, a distance of over $1600 \mathrm{~km}$. Nor are these organisms restricted to seamounts in many cases. For example, a new species of the Nephtheidae (G. C. Williams \& L. Lundsten unpubl.) was initially discovered at Rodriguez Seamount in 2004, but it has since been observed and collected from San Juan Seamount (southern California), Monterey Canyon, Pioneer Seamount, and the continental shelf off northern California and central Oregon. The range of this new species likely exceeds the $1200 \mathrm{~km}$ our data currently shows. Another example is Araeosoma leptaleum, an urchin in the family Echinothuriidae, which was originally described from a specimen collected off Panama (Mortensen 1935). We observed A. leptaleum in high abundance at the Rodriguez Seamount 'kelp falls', but it was absent from Davidson Seamount and only rarely seen at Pioneer Seamount $(\mathrm{n}=2)$. A new, branched form of the predatory sponge Asbestopluma was discovered at Davidson Seamount in February 2006. While not observed at Pioneer or Rodriguez Seamounts, this sponge was later observed during video analysis of other ROV 'Ventana' and 'Tiburon' dives within Monterey Bay and the Eel River Basin (L. Lundsten unpubl. data). Cladorhiza pteron (Reiswig \& Lee 2007), a new species of predatory sponge, was described from a specimen collected at Rodriguez Seamount in 2004, but this species was also seen at San Juan Seamount on that same expedition, although the data from San Juan Seamount are not presented here.

Many studies have concluded that rates of endemism at seamounts can be very high (Richer de Forges et al. 2000, Koslow et al. 2001); however, we found a considerable degree of overlap between the seamounts examined in the present study, the continental shelf, and other seamounts that have been surveyed by MBARI. This conclusion is in agreement with recent reports describing low rates of endemism at seamounts (Wilson \& Kaufmann 1987, Hall-Spencer et al. 2007, McClain 2007, O'Hara 2007, McClain et al. in press). Increased isolation due to distance from similar habitats or the continental margin would elevate the likelihood of endemism for seamount species. The low rates of endemism reported for the 3 seamounts studied here may very well be related to their near proximity to each other and to the continental margin.

Seamounts in general appear to provide habitat favorable to sessile suspension- and filter-feeding invertebrates because of the hard rock substrate and elevated current velocities often found there. Elevated current velocities tend to increase animal density due to 'feeding-pathways' and 'settlement-pathways', whereby more food and more larvae flow past a given area with increased current speed (Genin et al. 1986). Differences in community structure appear to be related to seamount shape, depth, nutrient availability, distance from shore or between seamounts, and ocean chemistry, and these factors must work in tandem, altering community composition to varying degrees by creating unique conditions at each seamount. Observations of the composition and distribution of sea- 
mount megafauna and their association with habitat characteristics provide some evidence for factors controlling seamount community structure, but lack the inferential power of manipulative field experiments and detailed documentation of important processes (e.g. recruitment, growth, and survival) in relation to variation in habitat qualities. Our understanding of ecological and evolutionary processes shaping seamount communities will undoubtedly benefit from such studies in the future.

Acknowledgements. We are grateful for support from the pilots of the ROV 'Tiburon' and the crew of the RV 'Western Flyer'. We also acknowledge the assistance of E. Lundsten, C. R. McClain, S. von Thun, W. Ussler III, K. Schlining, B. Schlining, L. Kuhnz, N. Jacobsen Stout, J. Connor, E. Burton and anonymous referees who helped improve the manuscript. Several taxonomists, including S. Cairns, H. Reiswig, W. Lee, G. Williams, C. Mah, C. Messing, and R. Mooi, contributed significantly to this study. This work was supported by the David and Lucile Packard Foundation and NOAA's Office of Ocean Exploration.

\section{LITERATURE CITED}

Andrews AH, Cordes EE, Mahoney MM, Munk K, Coale KH, Cailliet GM, Heifetz J (2002) Age, growth and radiometric age validation of a deep-sea, habitat-forming gorgonian (Primnoa resedaeformis) from the Gulf of Alaska. Hydrobiologia 471:101-110

Boehlert GW, Genin A (1987) A review of the effects of seamounts on biological processes. In: Keating BH, Fryer P, Batiza R, Boehlert GW (eds) Seamounts, islands, and atolls. Geophys Monogr 43:319-334

Brusca RC, Brusca GJ (1990) Invertebrates. Sinauer Associations, Sunderland, MA

Cairns SD (2007) Calcaxonian octocorals (Cnidaria; Anthozoa) from Eastern Pacific seamounts. Proc Calif Acad Sci 58:511-541

Clark MR, Tittensor D, Rogers AD, Brewin P and others (2006) Seamounts, deep-sea corals and fisheries: vulnerability of deep-sea corals to fishing on seamounts beyond areas of national jurisdiction. United Nations Environment Programme-World Conservation Monitoring Centre (UNEPWCMC), Cambridge

Clarke KR, Gorley RN (2001) Primer v6: user manual/tutorial. PRIMER-E Ltd., Plymouth

Colwell RK (2005) EstimateS: statistical estimation of species richness and shared species from samples, Version 7.5. User's guide and application. Available at: http://purl.oclc. org/estimates

Davis AS, Clague DA, Bohrson WA, Dalrymple GB, Greene HG (2002) Seamounts at the continental margin of California: a different kind of oceanic intra-plate volcanism. Geol Soc Am Bull 114:316-333

DeVogelaere AP, Burton EJ, Trejo T, King CE and others (2005) Deep-sea corals and resource protection at the Davidson Seamount, California, USA. In: Freiwald A, Roberts JM (eds) Cold-water corals and ecosystems. Springer-Verlag, Berlin, p 1189-1198

Etnoyer P, Cairns SD, Sanchez JA, Reed JK and others (2006) Deep-sea coral collection protocols. NOAA Technical Memorandum NMFS-OPR-28, Silver Spring, MD
Fosså JH, Mortensen PB, Furevik DM (2002) The deep water coral Lophelia pertusa in Norwegian waters: distribution and fishery impacts. Hydrobiologia 471:1-12

Fry GC, Brewer DT, Venables WN (2006) Vulnerability of deepwater demersal fishes to commercial fishing: evidence from a study around a tropical volcanic seamount in Papua New Guinea. Fish Res 81:126-141

Gage JD, Tyler PA (1992) Deep-sea biology: a natural history of organisms at the deep-sea Floor. Cambridge University Press, Cambridge

Genin A, Dayton PK, Lonsdale PF, Spiess FN (1986) Corals on seamount peaks provide evidence of current acceleration over deep-sea topography. Nature 322:59-61

- Genin A, Haury LR, Greenblatt P (1988) Interactions of migrating zooplankton with shallow topography: predation by rockfish and intensification of patchiness. DeepSea Res 35:151-175

Grigg RW (2002) Precious corals in Hawaii: discovery of a new bed and revised management measures for existing beds. Mar Fish Rev 64:13-20

Grigg RW, Malahoff A, Chave EH, Landahi J (1987) Seamount benthic ecology and potential environmental impact from manganese crust mining in Hawaii. In: Keating BH, Fryer P, Batiza R, and Boehlert GW (eds) Seamounts, islands, and atolls. Geophys Monogr 43. American Geophysical Union, Washington, DC, p 379-390

> Guinotte JM, Orr J, Cairns SD, Freiwald A, Morgan L, George R (2006) Will human-induced changes in seawater chemistry alter the distribution of deep-sea scleractinian corals? Front Ecol Environ 4:141-146

Hall-Spencer JM, Rogers A, Davies J, Foggo A (2007) Historical deep-sea coral distribution on seamount, oceanic island and continental shelf-slope habitats in the NE Atlantic. In: George RY, Cairns SD (eds) Conservation and adaptive management of seamount and deep-sea coral ecosystems. Rosenstiel School of Marine and Atmospheric Science, University of Miami, FL, p 135-146

Hooge PN, Eichenlaub B (1997) Animal movement extension to ArcView, version 1.1. Alaska Science Center-Biological Science Office, U.S. Geological Survey, Anchorage, AK

Kaufmann RS, Wakefield WW, Genin A (1989) Distribution of epibenthic megafauna and lebensspuren on two central North Pacific seamounts. Deep-Sea Res 36:1863-1896

Koslow JA (1997) Seamounts and the ecology of deep-sea fisheries. Am Sci 85:168-176

Koslow JA, Gowlett-Holmes K, Lowry JK, O'Hara T, Poore GCB (2001) Seamount benthic macrofauna off southern Tasmania: community structure and impacts of trawling. Mar Ecol Prog Ser 213:111-125

McClain CR (2007) Is seamount biogeography island biogeography? J Biogeogr 34:2001-2008

McClain CR, Lundsten L, Ream M, Barry JP, DeVogelaere AP (in press) The biogeography of deep-sea species: reflections on seamount endemicity, composition, and structure. PLoS One

McClatchie S, Coombs RF (2005) Spatial variability of orange roughy around the Northwest Hills on the Chatham Rise, New Zealand. Deep-Sea Res I 52:589-603

Mortensen T (1935) A monograph of the Echinoidea. Vol 2. Bothriocidaroida, Melonechinoida, Lepidocentroida and Stirodonta. C.A. Reitzel, Copenhagen

Mortensen PB, Buhl-Mortensen L (2005) Morphology and growth of the deep-water gorgonians Primnoa resedaeformis and Paragorgia arborea. Mar Biol 147:775-788

Mullineaux LS, Mills SW (1997) A test of the larval retention hypothesis in seamount-generated flows. Deep-Sea Res I 44:745-770 
O'Hara TD (2007) Seamounts: centres of endemism or species richness for ophiuroids? Glob Ecol Biogeogr 16:720-732

Parker T, Tunnicliffe V (1994) Dispersal strategies of the biota on an oceanic seamount: implications for ecology and biogeography. Biol Bull 187:336-345

Probert PK, McKnight DG, Grove SL (1997) Benthic invertebrate bycatch from a deep-water trawl fishery, Chatham Rise, New Zealand. Aquat Conserv: Mar Freshw Ecosyst $7: 27-40$

Reiswig HM, Lee WL (2007) A new species of Cladorhiza (Porifera: Cladorhizidae) from S California (USA). In: Custodio MR, Lobo-Hajdu G, Hajdu E, Muricy G (eds) Porifera research: biodiversity, innovation \& sustainability. Proc 7th Int Sponge Symp, May 2006, Buzios, p 517-523

Rex MA, Etter RJ, Morris JS, Crouse J and others (2006) Global bathymetric patterns of standing stock and body size in the deep-sea benthos. Mar Ecol Prog Ser 317:1-8

Richer de Forges B, Koslow JA, Poore GCB (2000) Diversity and endemism of the benthic seamount fauna in the southwest Pacific. Nature 405:944-947

Risk MJ, Heikoop JM, Snow MG, Beukens R (2002) Lifespans and growth patterns of two deep-sea corals: Primnoa resedaeformis and Desmophyllum cristagalli. Hydrobiologia 471:125-131

Rogers AD (1994) The biology of seamounts. Adv Mar Biol 30: 305-350

Editorial responsibility: James McClintock,

Birmingham, Alabama, USA
Rowden AA, O'Shea S, Clark MR (2002) Benthic biodiversity of seamounts on the northwest Chatham Rise. Marine biodiversity and biosecurity reports, MBBR 2, New Zealand Ministry of Fisheries, Wellington. Available at: www.fish.govt.nz/en-nz/info/aboutus/Organisation/Fisheries +Science/Science+Electronic+Documents+Database/MBBRs/ MBBR+2.htm

Schlining B, Jacobsen Stout N (2006) MBARI's video annotation and reference system. In: Proceedings of the Marine Technology Society/Institute of Electrical and Electronics Engineers Oceans Conference, Boston, MA, p 1-5

Stocks K (2004) Seamount invertebrates: composition and vulnerability to fishing. In: Morato T, Pauly D (eds) Seamounts: biodiversity and fisheries. 2004 Fisheries Centre Research Reports 12(5), UBC Fisheries Centre, Vancouver, p 17-24. Available at: www.seaaroundus.org/report/ seamountsF.htm

White M, Mohn C (2004) Seamounts: a review of physical processes and their influence on seamount ecosystems. OASIS (OceAnic seamounts) Report, University of Hamburg

Wilson RR, Kaufmann RS (1987) Seamount biota and biogeography. In: Keating BH, Fryer P, Batiza R, Boehlert GW (eds) Seamounts, islands, and atolls. Geophys Monogr 43. American Geophysical Union, Washington, DC, p 355-377

Submitted: May 13, 2008; Accepted: September 16, 2008 Proofs received from author(s): December 17, 2008 